\title{
DEHYDRATION OF ONION SLICES USING IR- REFRACTANCE WINDOW DRYING SYSTEM
}

\section{Tayel S.A. ${ }^{1}$, Alkatary H. S. ${ }^{1}$, Nagy K.S. ${ }^{2}$ and Younes O.S. ${ }^{3}$ \\ ABSTRACT}

The aim of this research work was to study the drying behavior of onion slices using infrared radiation refractance window drying system, which the infrared radiation passed throw plastic membrane surface, where the water in the moist product creates a window, that allows for the passage of infrared energy and heat behaves as it and directly transferred to water present in the product, the water in the product on the plastic membrane surface evaporates, and the window of infrared energy closes and refracts back into the heated source, no longer exposing the product to heat and good quality product.

The experiments of this work carried out at food engineering and packaging research dept. , Food Techn. Res. Institute, Agric. Research center. The drying behavior of onion slices using suggested dryer was examined and simulated for three different thin layer drying models ( Page, modified Page and Hendreson and Padis ).

Four levels of radiation intensity $\left(1100,1750,2400,3050 \mathrm{~W} / \mathrm{m}^{2}\right)$ and for levels of drying air velocity $(0.1,0.5,1$ and $1.5 \mathrm{~m} / \mathrm{s})$ were studied at $45^{\circ} \mathrm{C}$ temperature and $20 \%$ relative humidity.

The results showed that :

The recorded drying time for drying whole onion slices from an initial moisture content of about $612-614.28 \%$ d.b. to a final moisture content of about 13.75 - $15 \%$ d.b. were 50 - 140 minutes under different drying parameters.

- The following equation can described the relation ship between drying time $(T)$, radiation intensity $(I)$ and air velocity $(V)$ with the best fit :

$$
T=80+100 \mathrm{~V}-1600 \mathrm{I},
$$$$
\left(R^{2}=0.9911\right)
$$

(1) Prof. Emt.,Ag.Eng.Dept., Faculty of Agriculture, Al- Azher University.

(2)Senior Researcher and Head of Food Eng. and Pack. Res. Dept., Food Tech. Res. Inst., Agric. Res. Center.

(3) Assistant Researcher, Food Eng. and Pack. Res. Dept., Food Tech. Res. Inst., Agric. Res. Center. 
- The thermal efficiency of the IR-refractance window drying system was varied between $54.47 \%$ to $46.43 \%$, specific energy consumption varied between $4.39 \mathrm{KJ} \mathrm{kg}^{-1}$ to5.15 $\mathrm{KJ} \mathrm{kg}^{-1}$ under different drying parameters.

- The total capacity of the dryer is a bout $0.326 \mathrm{Kg} / \mathrm{h}$ the calculated operation cost of the dryer approaches about $8.89 \mathrm{LE} / \mathrm{kg}$ of dried whole onion slices .

\section{INTRODUCTION}

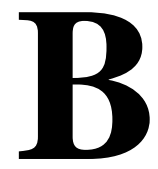

renden er al. ( 1999 ). Compared the following pilot plant dryers namly : Refractance window, drum, spray and freeze dryers, using energy efficiency, Beta carotene, tatal carotene, ascorbic acid ( vitamins ) and color retention of strawberries and carrots. They reported that the choice of strawberries and carrots was due to their importance as a source of vitamin and pro - vitamin A ( B - carotene ) respectively .

They summarized their results as follows . Energy efficiencies $27.9-$ $47.6 \%$ obtained for different drying conditions for the refractance window system were comparable to or slightly higher than the hot air methods ( $30-40) \%$ reported in the reported in the literature.

Vitamin $\mathrm{C}$ retention in refractance window dried strawberries were comparable to or higher than freeze - dried to a similar moisture content.

- Beta, Alpha and total carotene retention of refractance window dried carrots were comparable to freeze dried product and better than drum dried product.

- Color degradation in refractance window dried products was comparable to or slightly less than that of freeze dried products .

Feng et al.( 1999). Reported that drying kinetics in refractance window system for tested liquid foods generally followed the trend obtained for similar products using other drying methods, with no apparent constant rate period.

- Boudhrioua et al. (2003). Found that major disadvantages of hot air drying of foods are low energy efficiency, quality loss and lengthy drying time during the falling rate period. Because of the low thermal conductivity of food materials, heat transfer to the inner sections of food during conventional heating is limited. The desire to eliminate this 
problem, prevent significant quality loss, and achieve fast and effective thermal processing has resulted in the increasing use of infrared and microwaves for food drying. Dilip and Pankaj (2004). Showed that infrared drying technology is based on a property of water to absorb infrared (IR) radiation. Infrared radiation has a wavelength range from 0.75 to $100 \mathrm{~mm}$ subdivided into short-wave IR $(0.75-2 \mathrm{~mm})$, medium wave IR (2-4 mm), and long-wave IR $(4-100 \mathrm{~mm})$. The mechanism of bio-product drying is mass diffusion of water out of the bio-product and into the surrounding air. The infrared red rays penetrate to certain depth into the bio-products and increase its temperature. As a result of this temperature increase, the diffusion rate of water through the bio-product is increased and the water is vaporized at the surface of the material. The moisture is taken up by the drying air and provides in a fast rate of drying. Hebbar et al. (2004). Developed a combined infrared and hot air heating system for drying of vegetables. A conveyor sed drying system having three chambers was fitted with mid-infrared (MIR) heaters for irradiative heating. Through-flow hot air circulation was also provided for convective mode heating. The system was designed to operate under infrared, hot air and combination mode independently. The performance evaluation studies indicated that combination drying of carrot and potato at $80{ }^{\circ} \mathrm{C}$ with air at a velocity of $1 \mathrm{~m} / \mathrm{s}$ and temperature of $40{ }^{\circ} \mathrm{C}$ reduced the drying time by $48 \%$, besides consuming less energy (63\%) compared to hot air heating. Combination drying also gave better results over infrared heating alone. The energy utilization efficiency of the dryer was estimated to be $38 \%$ for both carrot and potato drying.

Sharma et al. (2005). Reported that the drying time reduced dramatically with increase in infrared power. They also, observed increased drying rates of food products with increasing power supply to infrared heater. The required drying time to reduce the moisture content of onion slice to about $0.06 \mathrm{~g}$ water / $\mathrm{g}$ dry matter at infrared power of 300,400 and $500 \mathrm{~W}$ was about 9,7 and 4 hours, respectively. The vapor pressure is considered to be a function of both temperature and moisture content. The increase in infrared power might have caused a rapid increase in the temperature at the product surface, resulting into an increase in the water vapor pressure inside the product and thus in higher 
drying rates. Kathira van Krishnamurthy, et. al (2008). Infrared(IR) heating provides significant advantages over conventional heating, including reduced heating time, uniform heating, reduced quality losses, absence of solute migration in food material, versatile, simple, and compact equipment, and significant energy saving. Infrared heating can be applied to various food-processing operations, namely, drying, baking, roasting, blanching, pasteurization, and sterilization..

\section{MATERIALS AND METHODS.}

\section{Material:}

\section{- The experimental dryer:}

Figures ( 1 ) illustrates the elevation and sid view of the design dryer used for experimental work.

The dryer consists of the following three main parts:

\section{- The Lower Cabinet:}

Is made of a double wall galvanized steel sheet with a thickness of 1.5 $\mathrm{mm}$, the space between both of the two walls is filled with glass wool insulator has a density of $16 \mathrm{~kg} / \mathrm{m}^{3}$. The cabinet has dimensions of $2.7 \mathrm{~m}$ length $\times 0.44 \mathrm{~m}$ width $\times 0.5 \mathrm{~m}$ height The lower cabinet contains the following parts:

-A conveyor belt made of transparent polyester with a thickness of 10 micron. This type of material allows highly IR ray penetration and can bear intensity of $4500 \mathrm{~W} / \mathrm{m}^{2}$ and tensile strength of $70 \mathrm{~N}$. The belt gets its motion manually

- A group of nine $250 \mathrm{~W}$ IR heating units (elements) are assembled under the conveyor belt using (L) shape $1.5 \mathrm{~mm}$ thickness galvanized steel holders in a way allows them sliding toward or outward the belt direction.

- the IR ray intensity was controlled by a dimmer.

- A stainless steel sliding sheet with a thickness of $1 \mathrm{~mm}$ assembled to the end of the cabinet for receiving and directing the outlet dried material.

A brush is assembled below the plastic membrane surface for cleaning it of residues. - Has been allocated a small room in the cabin the bottom 
contains on A single air heating element 2000 Watt power are often used to heat the air inside to $45^{\circ} \mathrm{C}$.

\section{- The upper Cabinet:}

Has a conical shape with dimensions of $1.7 \times 0.44 \times 0.85 \mathrm{~m}$ is made of a double wall galvanized steel sheet with a thickness of $1.5 \mathrm{~mm}$, the space between both of the two walls is filled with glass wool insulator has a density of $16 \mathrm{~kg} / \mathrm{m}^{3}$.

The upper cabinet contains the following parts:

- A group of eight $250 \mathrm{~W}$ IR heating units (elements) are assembled above the conveyor belt (in the lower cabinet) using (L) shape $1.5 \mathrm{~mm}$ thickness galvanized steel holders in a way allows them sliding toward or outward the belt direction.

Both groups of IR units above and under the plastic membrane surface are placed in a reciprocal order that allows

the similarity of distributing the ray intensity on the transparent belt total area that is controlled by a Dimmer.

- A lateral box contains control units for controlling the plastic membrane surface linear speed, ray intensity and air velocity .

\section{- Air Blower:}

- An air blower and a PVC flexible tube was used to exhaust the moist air that is controlled using a disc shape damper assembled on the shaft of a stepper motor. The damper gets its motion from a stepper motor

\section{- Control System:}

Control system was used to control the different functions of the dryer and is connected to a desk PC with a special designed software.The control system consists of the following devices:

\section{- power Suply:}

A control device was used to control the direction and the angle of the stepper motor disc (damper) in order to control in velocity of moist air .

\section{- Dimmer for Controlling the IR Ray Intensity:}

A dimmer was used to control the ray intensity of the IR heating elements

\section{2- Tested Crop:}

The white onion the initial moisture content of the freshly harvested ranged from $612 \%$ to $614 \%$ (dry basis) and the drying runs were stopped when the final moisture content reached about $8 \%$ (w.b). 

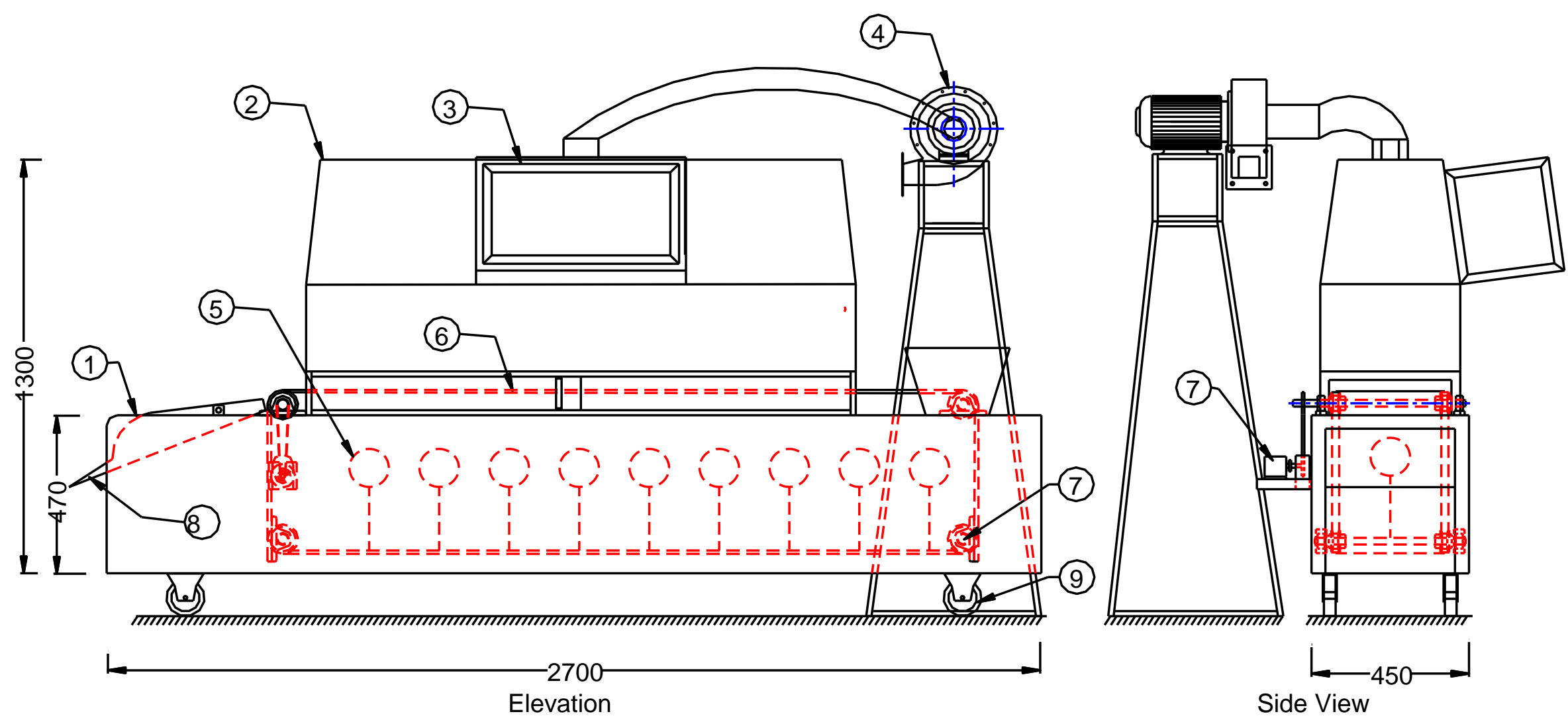

Figures (1) Experimental IR-Refractance window . 


\section{3-Measuring equipment :}

\section{- Ray Intensity:}

Ray intensity was measured by using Campbell Stokes Sunshine Recorder .The specifications of the instrument are listed in Table (1). Technical Details Adjustment for latitude :Table (1).

Tropical -45 to $65 \mathrm{~N}$ or $\mathrm{S}$

Sphere: $102 \mathrm{~mm}+/-1.3 \mathrm{~mm}$ diameter.

Focal length for sodium D light, $74.9 \mathrm{~mm}+/-0.25 \mathrm{~mm}$

Dimensions : $240 \times 187 \times 165 \mathrm{~mm}$

Weight: $4.3 \mathrm{Kg}$

\section{- Digital velocity stick :}

It was used to measured air velocity . It has the following specifications are. Technical data:

Model : It is model (testo 405-V I )

Measurement range ( 0 to $400 \mathrm{~m} / \mathrm{min}$ )

Accuracy : $( \pm 0.10 \mathrm{~m} / \mathrm{min})$.

\subsubsection{Digital temperature stick :}

It was used to measure air temperature. Its specifications are .Technical data: Model : It is model (testo 905-T I)

Sensor thermocouple; type kMeasurement range : $\quad-50$ to $+350{ }^{\circ} \mathrm{C}$ : short - term to $+500{ }^{\circ} \mathrm{CAccuracy}$ : (referred to calibration temperature of $\pm 1^{\circ} \mathrm{C}$.

\section{- Digital humidity stick:}

It was used to measure air humidity . It has the following specifications are.Technical data :

Model : It is model (testo 605-H I )

Sensor thermocouple; type $\mathrm{k}$

Measurement range : 5 to $95 \% \mathrm{RH} /-20$ to $+70{ }^{\circ} \mathrm{C}$

Accuracy : (System accuracy at $\pm 3 \% \mathrm{RH})$.

\section{- Dried Material Colour :}

Dried material Colour was measured by using Hunter Color-meter . 


\section{- Cutting Machine :}

Slices of onion slices were prospered using a cutting machine The machine consists mainly of two parts : a movable part and a fixed part . The movable part had a circle slicing knife make the needed shape and dimension of slices.

\section{- A static balance :-}

It was used to weight Initial and final weights of each sample with an accurate to(0.01 gm ).

\section{- Material thickness measurement :( vocalic ) :-}

It was used to measure the thickness of the dried material, It is an important parameter for the drying experiments .

\section{- Stop watch :-}

A Stop watch was used to measure the drying time by minutes .

\section{- Electric Current Ampere and Volt:}

The electric current ampere and volt for the IR heating elements, air heating element, air blower motor and damper stepper motor was measured by using an electronic Avometer .

\section{4- Methods:}

\section{b ) Preparation of the onion (Type : White).}

1) Peeling the onion by using special machine .2) Washing. 3) Weight the peeling onion by digital balance. 4) Chopping the weight onion to $1 \mathrm{~mm}$ slices by thickness chopping machine. 5) Saturated the onion slices in mita sodium sulfite (Na2 S2 O5) by concentration of $0.3 \%$ duration 5 minutes .6) Washing the onion slices under way water to takeout the saturate water. 7) Put the slices in the dryer (100 gm).

\section{5- Experimental proceeding :}

Multie experiments were conducted to study the drying of onion slices using IR-refractance window,

The samples of products prepared as follows.

All the experiments were conducted at inlet air of $45 \mathrm{C}^{\circ}$ and at relative humidity $20 \%$. Four levels of radiation $1100-1750-2400$ and 3050 $\mathrm{W} / \mathrm{m}^{2}$ and four levels of air velocity of $0.1-0.5-1$ and $1 \mathrm{M} / \mathrm{s}$ were 
examined The thicknesses of products were $6 \mathrm{~mm}$. Drying behavior, specific energy, thermal efficiency, quality of final product and cost analysis were studied for products using window drying method.

\section{6- Measurements and Calculations:}

\subsubsection{Moisture content of products :}

by vacuum oven at $343 \mathrm{k}^{\mathrm{o}}$ until (A. O.A.C, 1985)

\section{- Specific energy consumption :-}

The specific energy requirement for moisture removal was calculated according the following equation :

\section{Total energy consumption $(\mathbf{K} \mathbf{j})$}

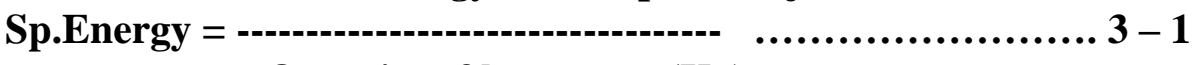

\section{Quantity of lost water $(\mathrm{Kg})$}

The energy consumption during the drying process is the sum of energy required for heating the ambient air and the supplied net infrared energy. For each experimental run, the energy consumption was calculated using the following relationship (Afzal et al. (1999)

Energy consumption $=3.6$ P D = 3.6 I V D (Kj).............. 3 - 2

Where:-

$$
\begin{array}{lc}
\mathrm{P}=\text { power consumption } & \mathrm{W} \\
\mathrm{I}=\text { amperage } & \mathrm{A} \\
\mathrm{V}=\text { voltage } & \mathrm{V} \\
\mathrm{D}=\text { drying time } & \mathrm{h}
\end{array}
$$

\section{- Thermal efficiency of the dryer :-}

In order to evaluate the overall performance of the dryer. Thermal efficiency was determined from actual drying tests. The thermal efficiency $(\eta)$ was calculated using the following relationship according to Jindal and Reyes ( 1987 ) .

\section{- quality measurements:}

- Rehydration ratio: The rehydration capacity was evaluated according to Sacilik and Unal, (2005).

\section{- Colour of the dried onion slice:}

The appearance of both fresh and dehydrated slices was assessed by a colour-difference meter. using a Hunter Lab Colorimeter. According to (Sharma and Prasad, 2006). 


\section{- Cost analysis.}

The operation cost of the best designed dryer was calculated according to a modified form of the equation of Awady, (1993). This equation is:

$\mathrm{C}=(\mathbf{P} / \mathbf{H})(\mathbf{1} / \mathbf{Y}+\mathbf{I} / \mathbf{2}+\mathbf{T}+\mathbf{M})+\mathbf{e}+(\mathbf{s} / 144)$ 3 - 3

Where: $\mathbf{C}$ (total hourly cost), $\mathbf{P}$ (initial price or capital of dryer .

$\mathbf{H}$ (estimated yearly-operating hours. Y (estimated life-expectancy of dryer in years . I (investment or overhand rates, T (taxes and overhead rates, $\mathbf{M}$ (maintenance and repairs ratio to capital head. $\mathbf{E}$ (electric-energy cost .

Actual machine production productivity $(\mathrm{Kg} / \mathrm{h}$ ) $=$ Mass onion slices $(\mathrm{Kg})$

Time of drying time $(h)$

Machine cost ( LE. / h )

Operation cost $(\mathrm{LE} / \mathrm{Kg})=$ $3-5$

Actual machine production productivity ( $\mathrm{Kg} / \mathrm{h}$ )

Table (2): Values of drying time, operation cost, capacity of dryer $(\mathrm{Kg} / \mathrm{h})$ and drying cost per $\mathrm{kg}$ of product when using radiation intensity $2400 \mathrm{~W} / \mathrm{m}^{2}$ and air velocity $0.1 \mathrm{~m} / \mathrm{s}$.

\begin{tabular}{|c|c|c|c|c|}
\hline $\begin{array}{c}\text { Type of } \\
\text { product dried }\end{array}$ & $\begin{array}{c}\text { Drying } \\
\text { time (h) }\end{array}$ & $\begin{array}{c}\text { Operating } \\
\text { cost of dryer } \\
(\mathrm{LE} / \mathrm{h})\end{array}$ & $\begin{array}{c}\text { Capacity of } \\
\text { dryer }(\mathrm{Kg} / \mathrm{h})\end{array}$ & $\begin{array}{c}\text { Drying cost } \\
\text { per kg of } \\
\text { drying } \\
\text { product } \\
(\mathrm{LE} / \mathrm{Kg})\end{array}$ \\
\hline \hline Onion slices & 1.08 & 1.79 & 0.592 & 3 \\
\hline
\end{tabular}

\section{4-RESULTS AND DISCUSSION}

\subsection{IR-Refractance Window Method for Drying Onion Slice:}

\subsubsection{Behavior of Refractance Window Drying System of Onion} Slice.

The different air velocity and different infrared radiation on moisture content, drying rate and moisture ratio of onion slice at thin layer (thickness $4 \mathrm{~mm}$ ) of refractance window drying system all the experiments were conducted at inlet air temperature of $45^{\circ} \mathrm{C}$ 
at relative humidity $20 \%$, with four levels of radiation intensity (1100 $1750-2400$ and $\left.3050 \mathrm{~W} / \mathrm{m}^{2}\right)$ and four levels of air velocity of $(0.1-0.5-1$ and $1.5 \mathrm{M} / \mathrm{s}$ ) were also examined. The thicknesses of onion slice were $4 \mathrm{~mm}$.

\subsubsection{Influence of radiation intensity and air velocity on drying} carves :-

The change in moisture of onion slice as relate time for different air velocity and different radiation intensity in IR-refractance window drying system are illustrated in figures (4-1). As shown in figure that the moisture content of onion slice decreased continuously with time at increasing radiation intensity and decreased air velocity .

Figures (2) and (3) show the variation of drying rate with change in onion slice moisture content or drying time. The figures show that , the drying rate of onion slice was decreased with the decrease of moisture content or in other words with the increase of drying time due to the reduction in onion slice moisture content.

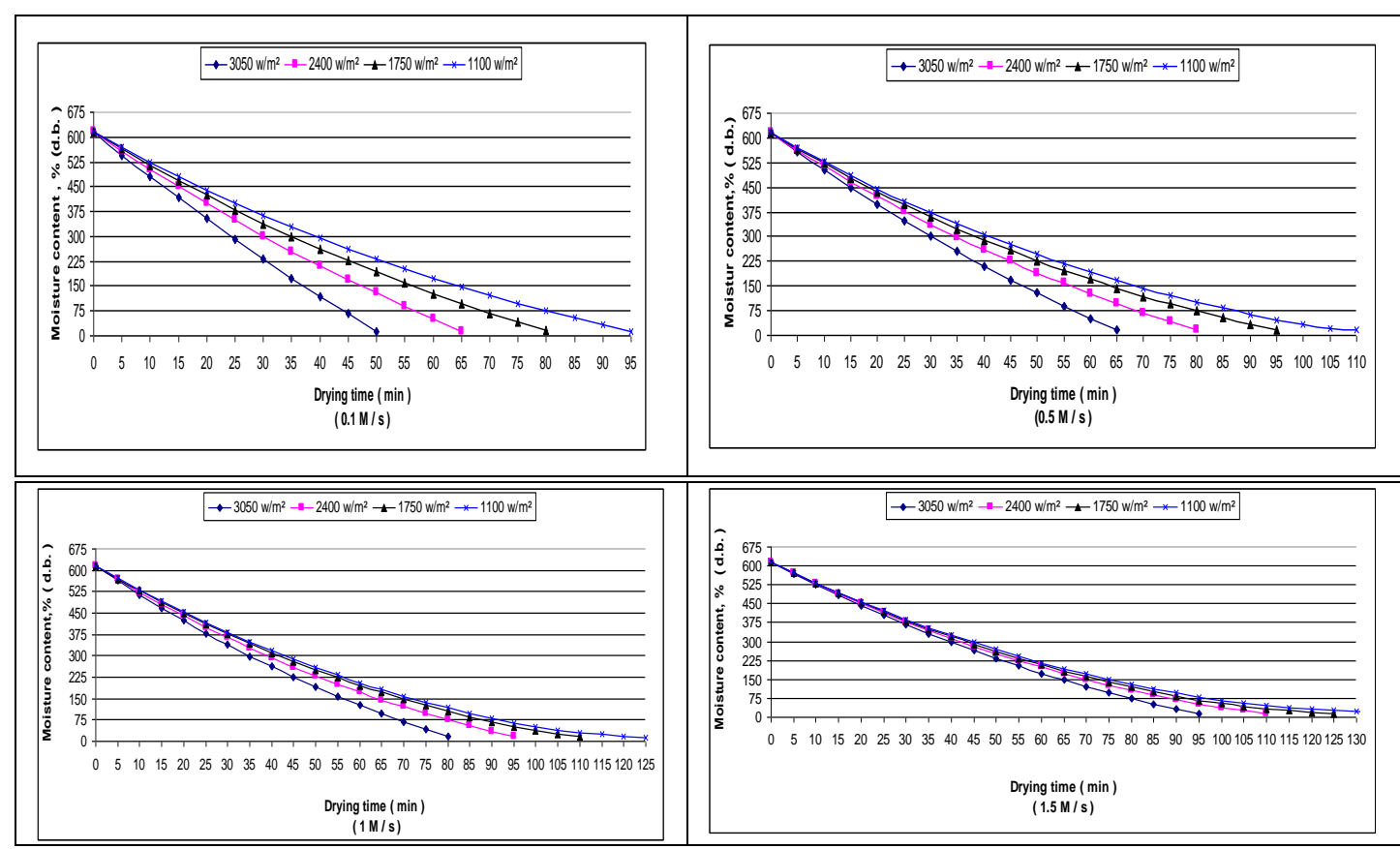

Figure (2): Variation of moisture content of onion slice as related to drying time at different air velocity and at different intensity in IR-refractance window drying system. 

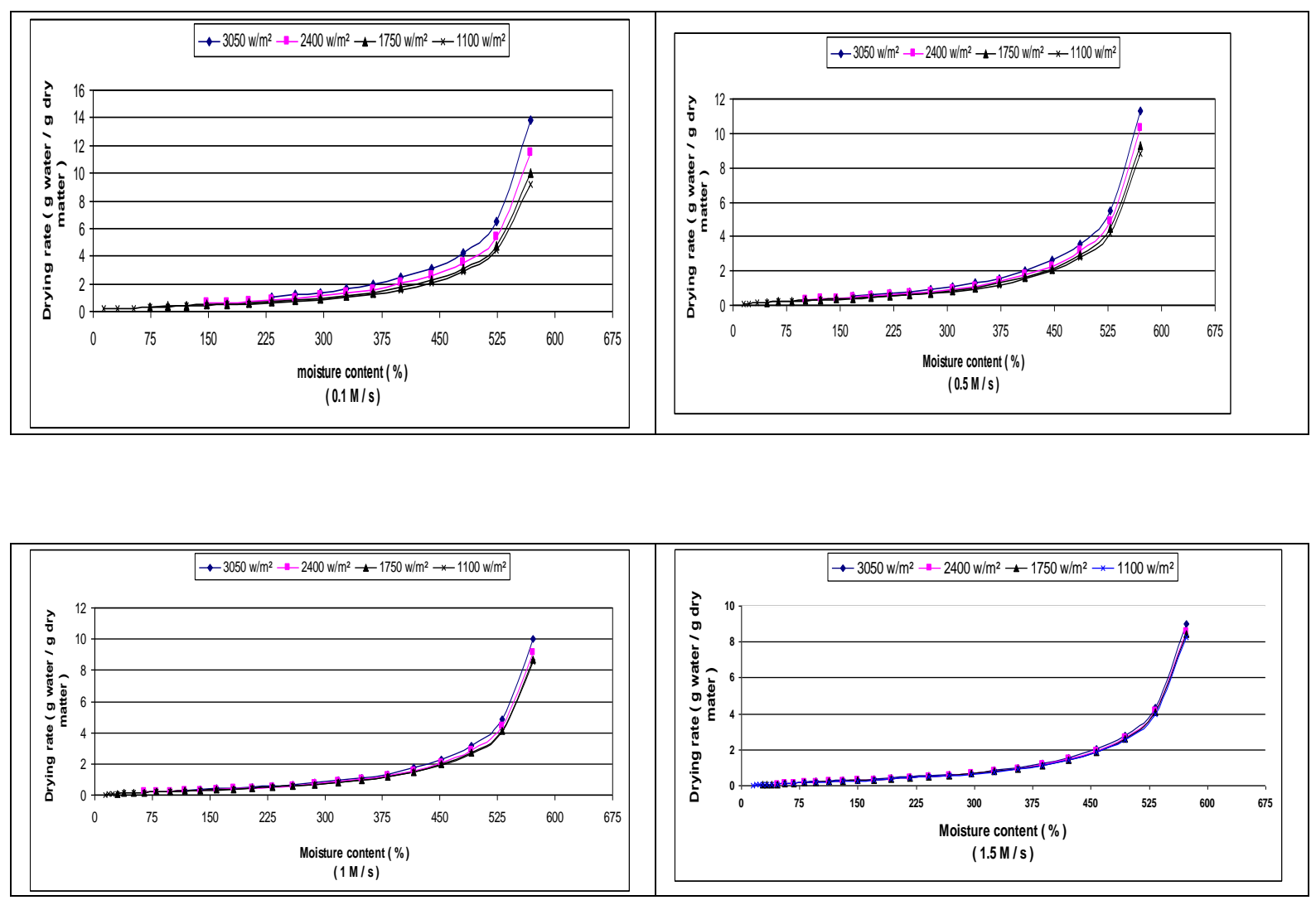

Figure (3): Variation of drying rate of onion slice as related to moisture content at different air velocity and at different intensity in refractance window drying system

In these figures the constant rate drying period is absent; the drying process took place in the falling rate period. In general the drying rate of onion slice increased with the increase of radiation intensity and decrease of air velocity. At the minimum air velocity of $0.1 \mathrm{~m} / \mathrm{s}$ and radiation intensity of $1100,1750,2400$, and $3050 \mathrm{~W} / \mathrm{m}^{2}$ the overall average drying rate during the drying process were $1.450,1.844,2.502$ and $3.741 \mathrm{~g}$ water $/ \mathrm{g}$ dry matter respectively, while, at the maximum air velocity of $1.5 \mathrm{~m} / \mathrm{s}$ and radiation intensity of $1100,1750,2400$, and $3050 \mathrm{~W} / \mathrm{m}^{2}$ the corresponding drying rate were $0.906,1.032,1.191$ and $1.438 \mathrm{~g}$ water/g dry matter respectively. 


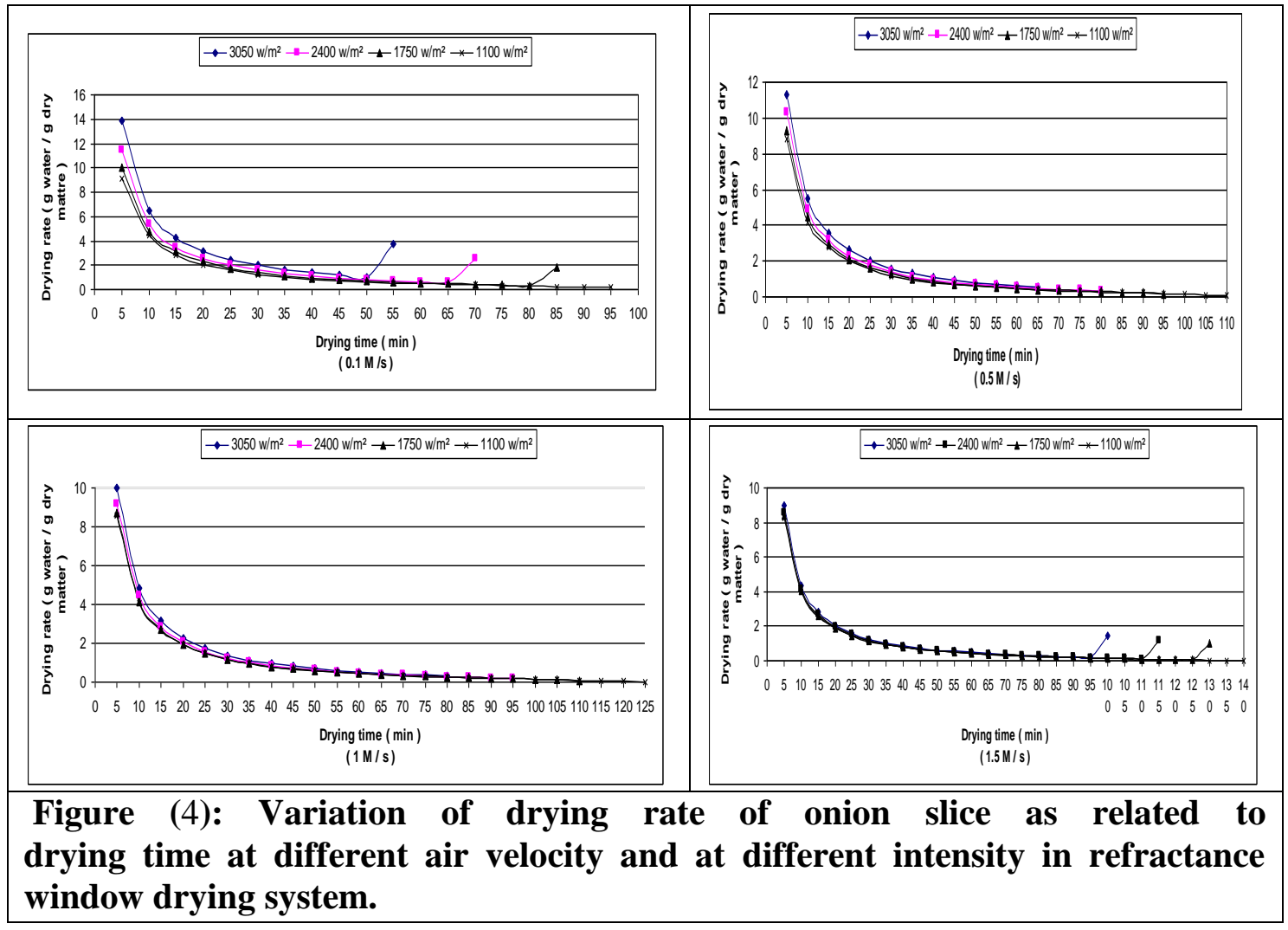

The moisture ratio against time for thin layer drying of onion slice at different radiation intensity and different air velocity for IR-refractance window drying system are shown in figure (4). The effect of increasing the radiation intensity on drying rate, when air velocity was constant is evident. The figure (5) show that, the moisture ratio decreased with the increased of drying time. The reduction rate of moisture ratio increased with the increasing of radiation intensity while it was decreased with the increase of air velocity.

\section{Influence of radiation intensity and air velocity on drying time( $T)$.}

Figure (6) illustrate the relation between drying time and both intensity and air velocity for IR-refractance window drying system. Generally it can be observed that, the drying time decreased with the increasing of radiation intensity and decreasing of air velocity. This condition may be due to the radiation intensity increased; high heat flux provided by the infrared heating causing rapid rise of onion slice temperature toward the end of the drying process, with corresponding increase of the drying rate and hence decreases of drying time. The increase in drying time by increasing air velocity may be due to lowering of onion slice temperature and hence the drying rate as previously mentioned the observed onion 
slice temperature decreased with the increase in air velocity at all levels of radiation intensity.
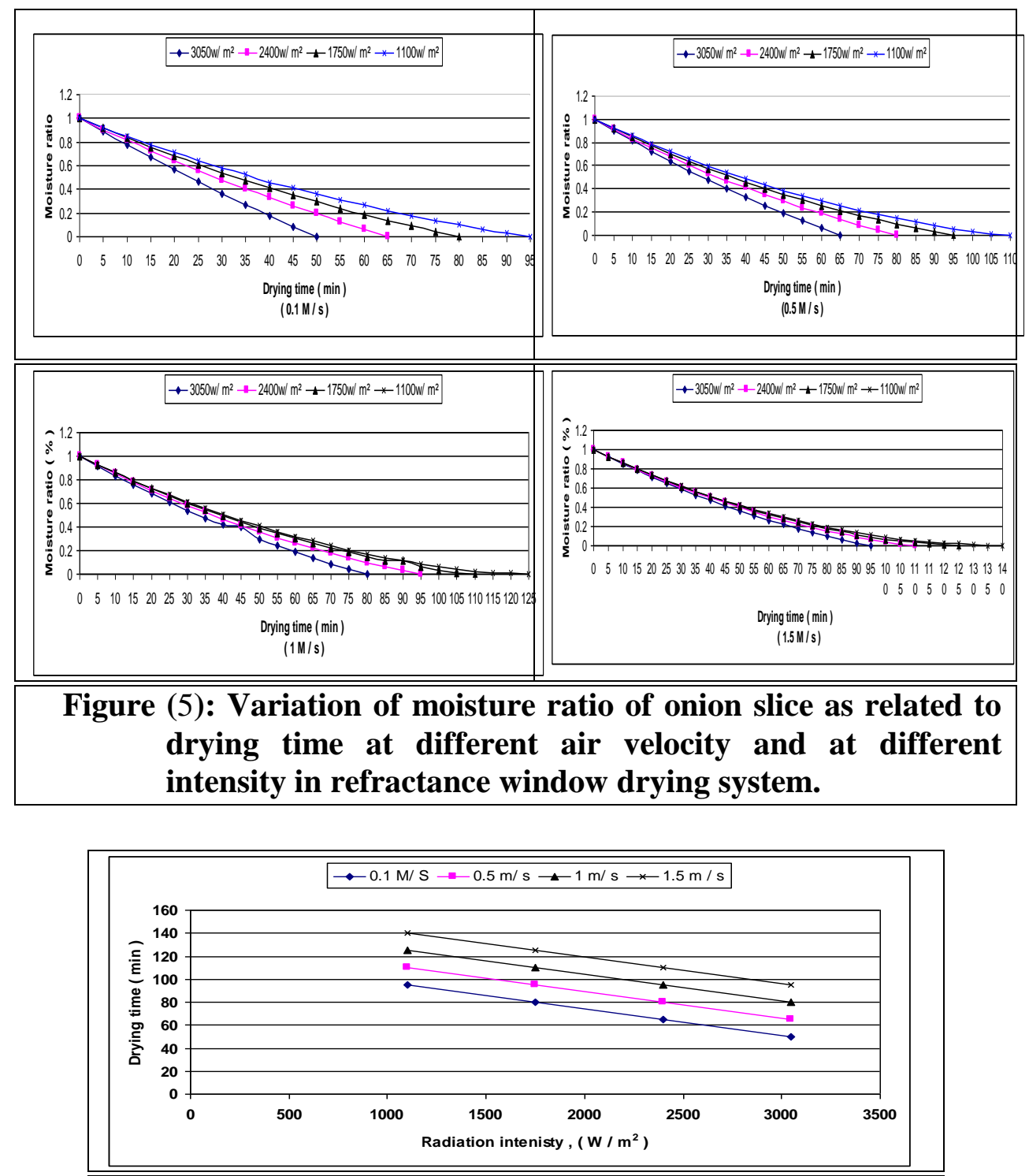

Figure (6): - The Effect of different radiation intensity and different air velocity on drying time of onion slice in IRrefractance window drying system.

Changing the radiation intensity from 1100 to $3050 \mathrm{~W} / \mathrm{m}^{2}$ at the minimum air velocity of $0.1 \mathrm{~m} / \mathrm{s}$ decreased the drying time form 95 to 50 
min. while at the maximum air velocity of $1.5 \mathrm{M} / \mathrm{s}$ the drying time decreased from 140 to $95 \mathrm{~min}$. A multiple regression analysis was proceeded to describe the relationship between the drying time $(\mathrm{T})$, radiation intensity (I) and air velocity (V) for refractance window, the regression equations for the best fit was as the following:

$\mathrm{T}=80+.01 \mathrm{~V}-2195 \mathrm{I}, \quad\left(\mathrm{R}^{2}=0.9911\right)$

\section{Specific energy consumption, thermal efficiency and quality of} refractance window drying system of Onion Slice.

\section{Specific Energy Consumption :}

Figure ( 7): illustrated the effect of infrared radiation intensity and air velocity on the specific energy consumption of IR-(R.W.) drying system. The specific energy consumption increased with the increasing radiation intensity. Changing the radiation intensity from 1100 to $3050 \mathrm{~W} / \mathrm{m}^{2}$.

At the minimum air velocity of $0.1 \mathrm{~m} / \mathrm{s}$ increased the specific energy consumption 4.39 to $5.15 \mathrm{KJkg}^{-1}$ of water while at the maximum air velocity of $1.5 \mathrm{~m} / \mathrm{s}$ the specific energy consumption increased from 6.48 to $9.82 \mathrm{KJkg}^{-1}$ of water of water of IR- (R.W.) drying system.

In general, the specific energy consumption increased by increasing air velocity, as a result of lowering the onion slice temperature and hence decreasing the drying rate.

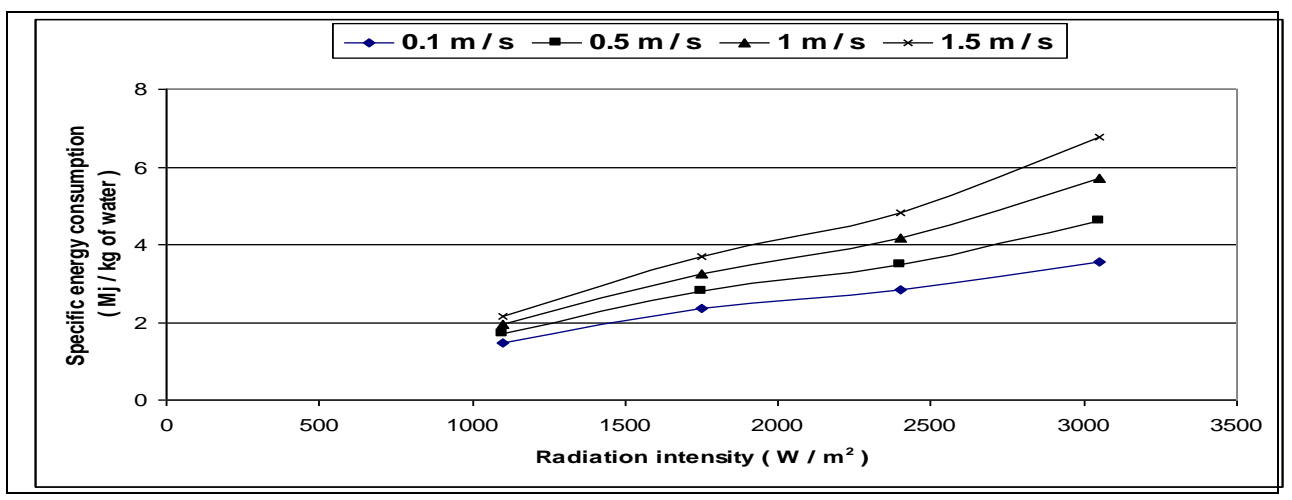

Figure (7): Specific energy consumption as related to different radiation intensity and different air velocity in refractance IRwindow drying system of onion slice. 


\section{4-Thermal Efficiency :-}

Figure (8): show the effect of radiation intensity and air velocity on thermal efficiency of IR- (R.W.) drying system. The thermal efficiency increased by the decreasing radiation intensity and decreasing air velocity.

Increasing the radiation intensity from $1100-3050 \mathrm{~W} / \mathrm{m}^{2}$ at the minimum air velocity of $0.1 \mathrm{~m} / \mathrm{s}$ decreased the thermal efficiency from 54.47 to $46.43 \%$ respectively on the other hand, at the maximum air velocity of $1.5 \mathrm{~m} / \mathrm{s}$ the thermal efficiency decreased from 36.85 to $24.39 \%$ of IR-(R.W.) drying system.The decreased of thermal efficiency with increase of radiation intensity my be due to the increase of total specific energy consumption with increasing radiation intensity. Mean while, increasing of total specific energy consumption with the increase of air velocity decreased the onion slice temperature and hence, decreasing the drying rat and increasing the drying time and total specific energy consumption which finally the thermal efficiency decreased.

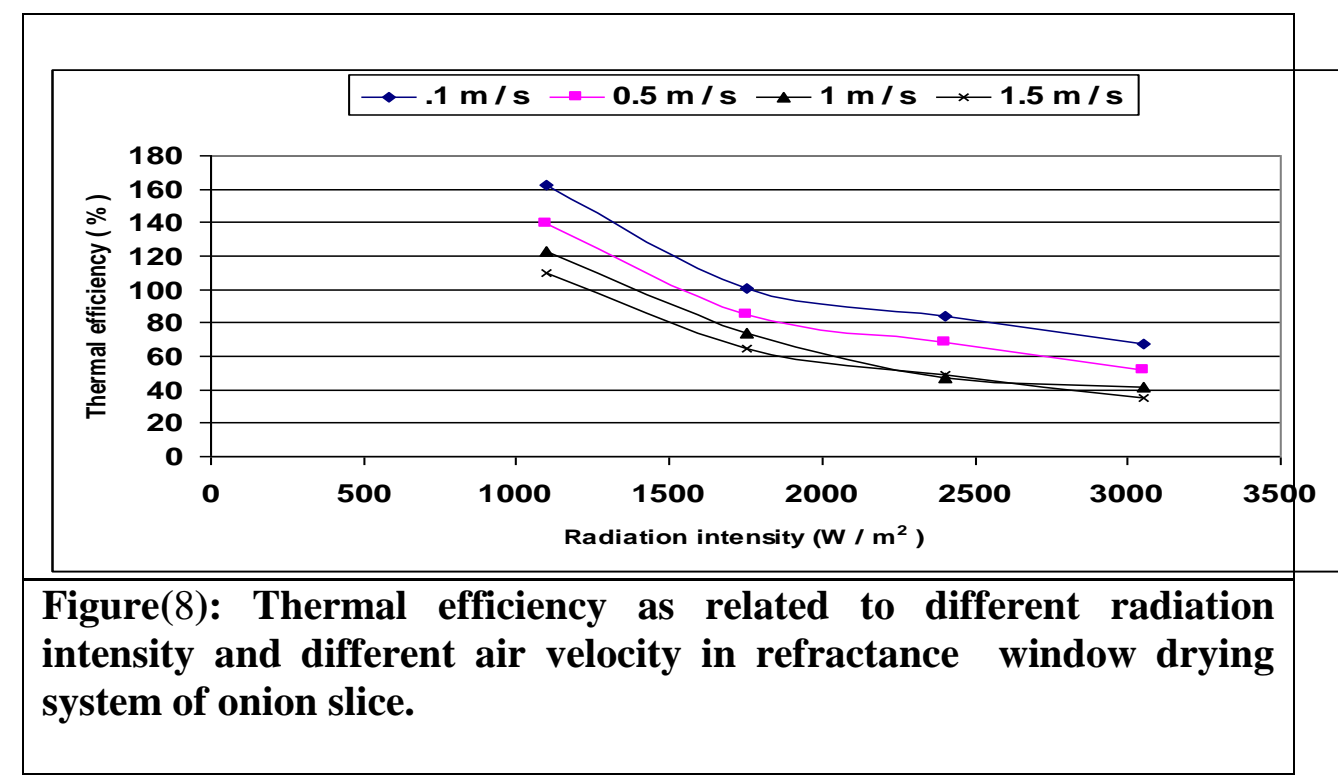

\section{Onion Slice Quality :}

\section{a. The Rehdration Ratio of Onion Slice :}

Figure (9) present the effect of infrared radiation intensity and air velocity on the rehydration ratio of onion slice of IR- (R.W.) drying system.The rehydration ratio increased with the increasing of infrared 
radiation intensity. This is due to the increased rate of moisture removal with the increase of radiation intensity which causes less shrinkage of the dried onion slice thus facilitating the rehydration process.

Changing the radiation intensity from 1100 to $3050 \mathrm{~W} / \mathrm{m}^{2}$ at the minimum air velocity of $0.1 \mathrm{~m} / \mathrm{s}$ increased the rehydration ratio from 95.1 $\%$ to $95.6 \%$ respectively while, it was increased from $91.4 \%$ to $94.4 \%$ at the maximum air velocity of $1.5 \mathrm{~m} / \mathrm{s}$. The decrease of rehydration ratio by the increase of air velocity may be due to the lower rate of moisture removal from onion slice as a result of onion slice temperature reduction which cause a high shrinkage of the dried onion slice .

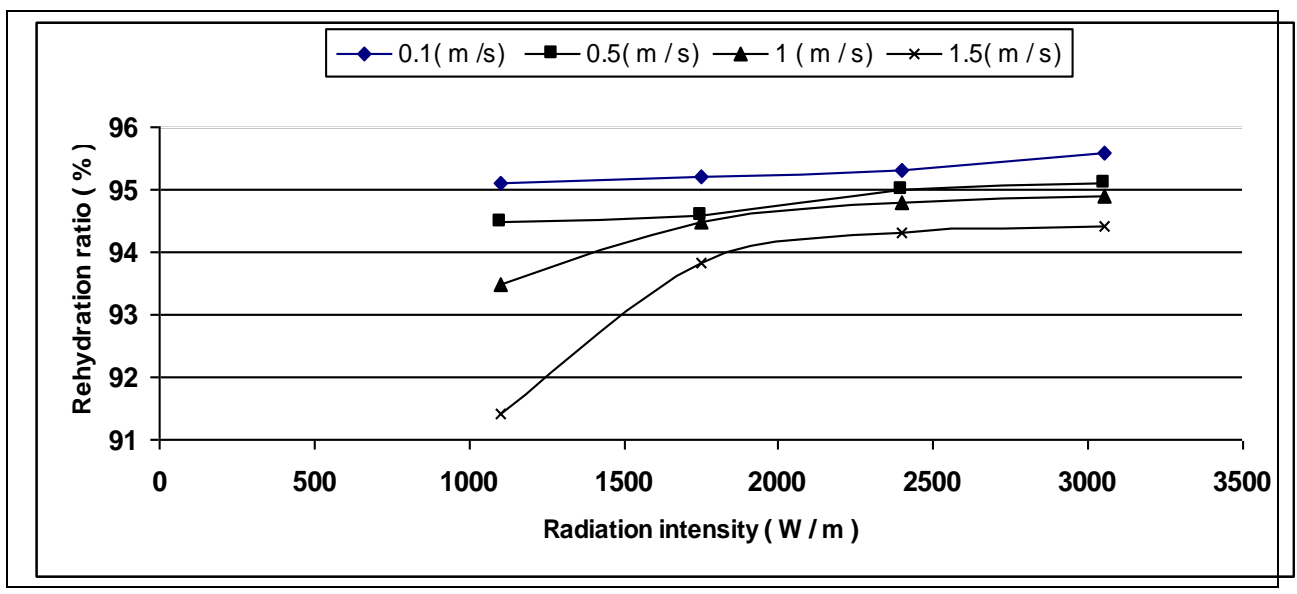

Figure (9):-The effect of different radiation intensity on the rehydration ratio $(\%)$ of onion slice at different air velocity ( 0.1 $0.5-1-1.5 \mathrm{~m} / \mathrm{s}$ ) in refractance window drying system.

\section{b. Colour change of Onion Slice:}

Figure (10) show the effect of infrared radiation intensity and air velocity on the colour difference of onion slice of refractance window drying system. The colour difference increase of infrared radiation intensity. Changing the radiation intensity from 1100 to $3050 \mathrm{~W} / \mathrm{m}^{2}$ at the minimum air velocity of $0.1 \mathrm{~m} / \mathrm{s}$ increased the colour difference from from 21.5 to 28 . While at the maximum air velocity of $1.5 \mathrm{~m} / \mathrm{s}$ the colour difference increased from 12 to 20. Also the colour difference increased by the increase of air velocity. This is because the decrease of onion slice temperature by the increase of air velocity. 


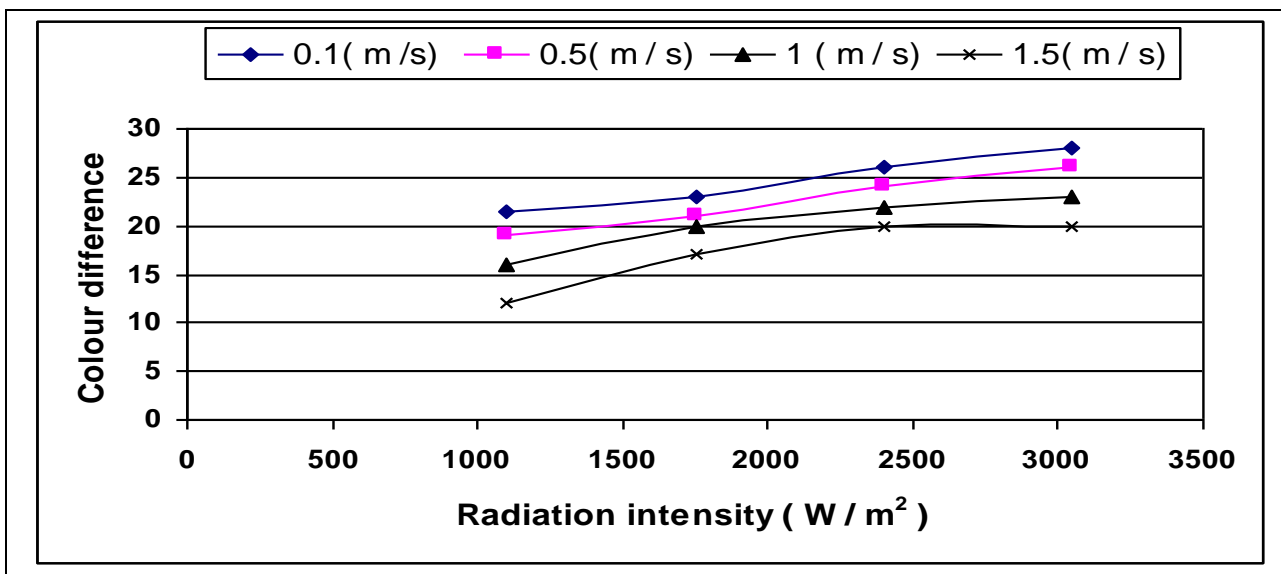

Figure (10):-The effect of different radiation intensity on the Colour difference $(\Delta E)$ of onion slice at different air velocity $(0.1$ - 0.5 -1- 1.5 $\mathrm{m} / \mathbf{s}$ ) in refractance window drying system.

\section{6- REFERENCE}

A.O.A.C. (1995). Official method of analysis, association of official analytical chemists. Washington, D.C. USA.

Afzal, T. M., Abe, T., \& Hikida, Y. (1999). Energy and quality aspects during combined FIR-convective drying of barley. Journal of Food Engineering, 42, 177-182.

Awady, M. N., Mohamed, S.A., El Sayed, A. S., and Hassanain, A. A., (1993). Utilization of solar energy.

Boudhrioua,N.; P.Giampaoli and C.Bonazzi (2003): "Changes in aromatic components of banana during ripening and air drying". Lebensmittel Wissenschaft und Technology, 36: 633-642.

Brendan, I.A., T Juming and G.E Charles (1999). Evaluation of the energy efficiency and quality retention for refractance window system. Dept. Of Biological systems Eng. Washington stat. Univ. Project report 1-36. 
Dilip,J. and B.P.Pankaj (2004): "Selection and evaluation of thin layer drying models for infrared radiative and convective drying of onion slices". Biosystems Engineering, 89 (3): 289-290.

Feng, H,J. Tang and R.P. Cavalierie (1999) . combined microwave and sprouted bed drying of diced apples : Effect of drying condition on kinetics and product temperature, Drying technology. 17 ( 10 ) $1981-1998$.

Henderson, S. M, and S. Pabis (1961). Grain drying theory. II. Temperature effects on drying coefficients. Journal of Agricultural Engineering Research, 6, 169-174.

Hebbar,H.U.;K.H.Vishwanathan and M.N.Ramesh (2004): "Development of combined infrared and hot air dryer for vegetables". Journal of Engineering, 65: 557-563.

Jindal, V.K. and V. G. Reyes, ( 1987 ). Conduction heating of rough rice accelerated drying. Paper no. 87-6043, American society of Agricultural Engineers (ASAE) Summer Metting Baltimore June 28 July 1, ASAE, sr. Joseph. Mi.

Page,G.E. (1949): "Factors influencing the maximum rates of air drying shelled corn in thin layers".M.S.Thesis, Department of Mechanical Engineering, Purdue University, Purdue, USA.

Sacilik,K. and G.Unal (2005):"Dehydration characteristics of Kastamonu garlic slices”. Biosystems Engineering, 92 (2): $207-$ 215.

Sharma,G.P.; R.C.Verma and P.B.Pathare (2005): "Mathematical modeling of infrared radiation thin layer drying of onion slices". Journal of Food Engineering, 71: 282-286.

Kathira van Krishnamurthy, Harpreet Kaur Khurana, Soojin Jun, Joseph Irudayaraj, and Ali Demirci (2008). Infrared Heating in Food Processing: An Overview. Comprehensive reviews in food science and food safety _ Vol 7, 2008 
الملخص العربح

\section{تجفيف شرائح البصل باستخدام نظام التجفيف الاتعكاسى للاشعة تحت الحمر اء

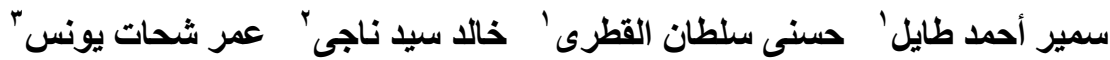

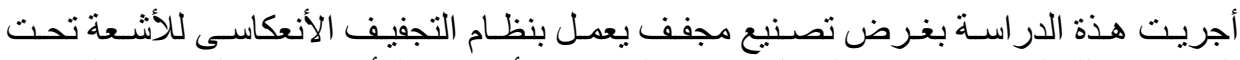

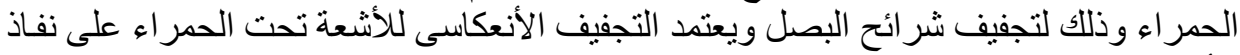

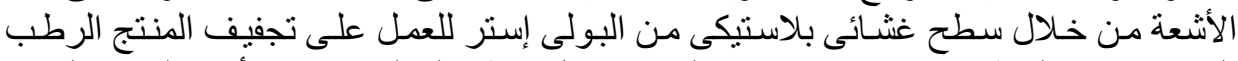

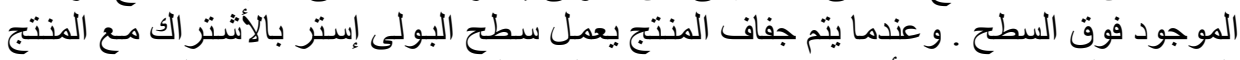

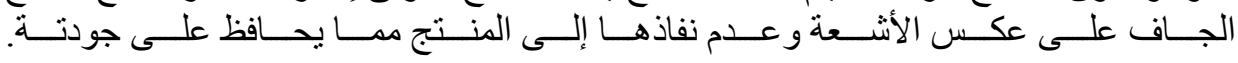

إجريت هذه الدر اسة بقسم بحوث هندسة تصنيع وتعبئة وتغليف الأغذية ـ معهد بحوث تكنولوجيا

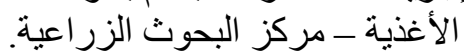

تمت دراسة سلوك تجفيف شر ائح البصل في طبقة رقيقة بإستخدام المجفف المقترح لأربعة

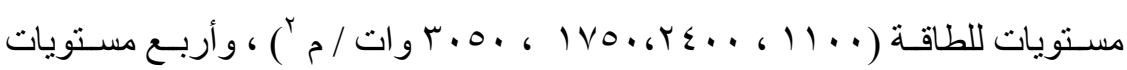

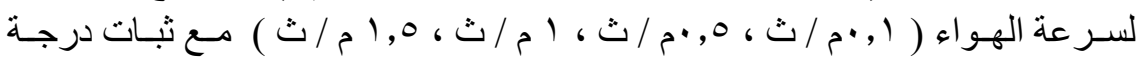

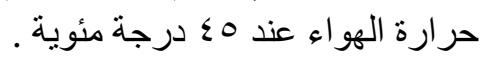

أظهرت النتائج المتحصل عليها أن :

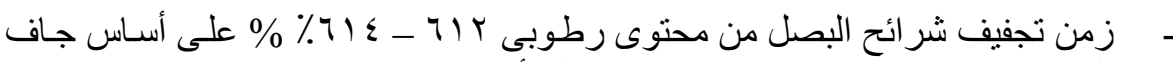

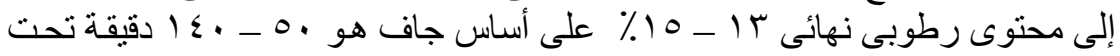

$$
\text { العو امل الدر اسية المختلفة فئية }
$$

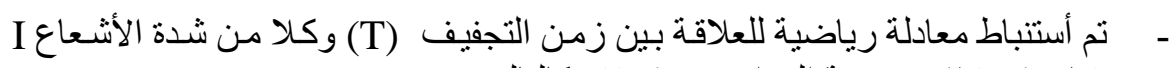

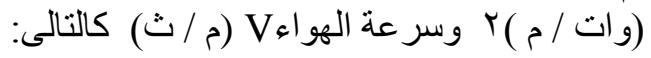

$$
\mathrm{T}=80+100 \mathrm{~V}-1600 \mathrm{I} \quad\left(\mathrm{R}^{2}=0.9911\right)
$$

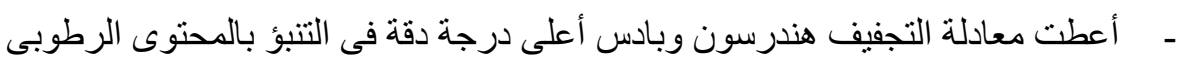

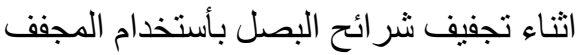

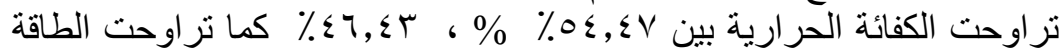

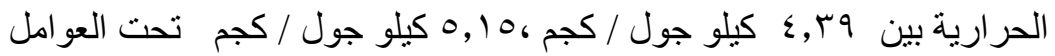

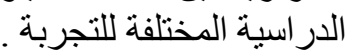

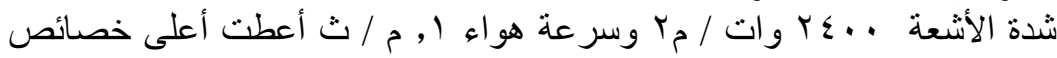

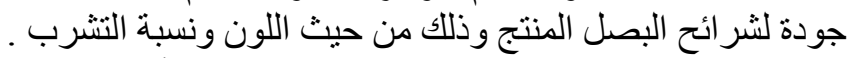

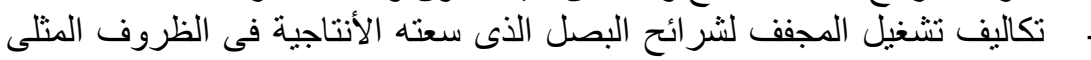

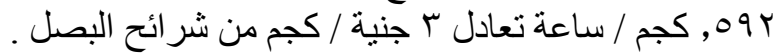

